\title{
CHINA AND THE DOLLAR: AN OPTIMUM CURRENCY AREA VIEW
}

\author{
Chee-Heong Quah, Patrick M. Crowley*
}

\begin{abstract}
:
This paper attempts to assess how compatible China is with respect to its dollar-based exchange rate regime. Assessment is made in terms of the real convergence criteria suggested by the optimum currency areas (OCA) theory. In light of the endogenous problem in OCA analysis and this view of convergence criteria, the relevant features of China are evaluated against economies implementing rigid dollar standard in practice, namely Hong Kong, Macau, and Panama. Findings suggest that economic conditions in China broadly conform to those prevailing in these economies which maintain strong links to the US dollar.
\end{abstract}

Keywords: optimum currency area; renminbi; China; Hong Kong; Macau; dollarization; exchange rate; money.

JEL Classification: E62, F31, F32, F41, F42, O53.

\section{Introduction}

In recent years, there has been intense debate on whether China should succumb to international pressures to revalue its renminbi at a faster rate than its present soft/ crawling peg, or to maintain this regime which has been in place since July 2005. Amongst the most vocal advocates of revaluation is Paul Krugman, who continues to call for appreciation of the renminbi at a much faster rate as an effective mechanism to adjust the US-China external imbalances (the so-called "China-bashing"). His stand is vividly reflected in the following excerpt from his New York Times column published on June 24, 2010:

* Chee-Heong Quah, Faculty of Business and Accountancy, University of Malaya, Kuala Lumpur 50603, Malaysia (quahch@um.edu.my); Patrick M. Crowley, College of Business, Texas A\&M University, 6300 Ocean Drive, Corpus Christi, TX 78412, USA. 
"This (Chinese) policy is very damaging at a time when much of the world economy remains deeply depressed. In normal times, you could argue that Chinese purchases of US bonds, while distorting trade, were at least supplying us with cheap credit - and you could argue that it wasn't China's fault that we used that credit to inflate a vast, destructive housing bubble. But right now we're awash in cheap credit; what's lacking is sufficient demand for goods and services to generate the jobs we need. And China, by running an artificial trade surplus, is aggravating that problem."

Krugman also added that the yuan-dollar peg has not only been hurting the American economy, but also China's, and has also stymied the recovery of the world from the global recession.

In contrast, McKinnon and Schnabl (2009) dismissed the potency of changes in nominal yuan-dollar rate in resolving the perennial imbalances between the two largest economies. According to them, for the US trade balance to improve with exchange depreciation, overall domestic expenditures in US must fall relative to aggregate output. In other words, domestic US savings must rise relative to domestic investment. Nevertheless, one cannot presume that US net saving will rise when the dollar is devalued - indeed, the reverse may be true. ${ }^{1}$

In the same vein, Zhang, Fung, and Kummer (2006) found that China's real exchange rate appreciation might cause Chinese output in both the primary and manufacturing sectors to increase whilst the outputs of the energy and services sectors decrease, leading to little or no changes in the current account balance. Historically, as Peng, Lee, and Gan (2008) discovered, even when the renminbi was overvalued in 1997-2002, China still experienced a huge trade balance surplus against US. In this connection, Hale and Hale (2008) argue that a growing Chinese trade surplus has actually produced numerous benefits for the world economy and in particular American corporations and consumers.

In view of this contention, instead of further disputing the merits of the peg, it may be important to ascertain the suitability of the existing Chinese dollar peg as supported by the economic characteristics of China. To do this, this paper assesses the appropriateness of China's present exchange rate regime, namely a crawling peg against the dollar, by comparing the economic characteristics of China to those of its close peripheries of Hong Kong and Macau, the effective dollar currency board economies since 1983 and 1989 respectively. In addition, since Panama has a more-than-a-century-old history of dollarization, that is, since 1901, the Chinese attributes are also evaluated against the Panama's.

1 Taking the lessons from the 1980s and the1990s Japan experience, sharp appreciation of the renminbi might set off a minor investment boom in the US, where investment expenditures rise from a relatively small base, but a major slump in China's huge investment sector which is currently about $45 \%$ of GNP. Overall, investment led expenditures including those from US firms in China would fall; contracting the Chinese economy and its imports. 
The dimensions explored are the real convergence criteria related to the optimum currency area (OCA) theory, over a 30-year period of 1980-2009. In some ways, the approach used here does take into account the endogeneity view of convergence criteria popularized by Frankel and Rose (1998). This is so because though China's currency has been pegged to the dollar, unlike Hong Kong and Macau which maintain strict currency board arrangements, the Chinese authorities have been sterilizing dollar inflows to maintain their control on the internal monetary base and inflation.

The findings would be useful for policymakers as they should indicate the feasibility for China to persist with its present crawling peg or perhaps more than that, to move to a stricter currency board system similar to Hong Kong and Macau's, or even a joint dollar-based arrangement with the two peripheral territories. A Greater China monetary union comprising of China, Hong Kong, and Macau could well be a stepping stone toward globalization of renminbi as Hong Kong is already an international financial hub. The issuance of yuan-denominated international bonds in Hong Kong in recent years shows that potentiality. ${ }^{2}$

The remainder of this paper is organized as follows. The next section introduces the OCA dimensions and assesses the dimensions of China with those of the "benchmark" economies. Finally, a discussion and conclusion is provided.

\section{Optimum Currency Area Criteria}

The foundations of the OCA theory were laid out by Mundell (1961), McKinnon (1963), and Kenen (1969) which outline the criteria under which a country or economic zone can reap significant benefits and/or substantially reduce the cost of joining a currency area.

Following Quah and Crowley (2010), the OCA criteria investigated here are trade openness, business cycle synchronization, real exchange rate variability, inflation convergence, real interest rate symmetry, export diversification, and labour market flexibility. Similar measurements of the variables were actually used earlier in Artis and Zhang $(2001,2002) .{ }^{3}$ Interestingly, the efficacy of the criteria was evidenced when Portugal, Italy, Greece, and Spain were selected as the group which exhibits the least similar OCA features against Germany. These member states are among the most distressed euro area members today.

To assess the appropriateness of China's dollar peg, the characteristics of the Chinese economy are measured against those of the US before the same is done for Hong Kong, Macau, and Panama. If the characteristics of the Chinese economy are more

2 See Wu, Pan, and Wang (2010) and Park (2010) for a discussion on the prospects of globalization of renminbi and its challenges.

3 Artis and Zhang (2001 and 2002), however, did not use an export diversification variable.For recent applications of the framework used in this paper, see Quah (2012a; 2012b; 2012c); Quah and Ismail (2012) and Quah and Crowley (2012). 
conforming than some established benchmarks from the other countries then this operationalization of the OCA theory might indicate feasibility for China to persist with its dollar peg, or perhaps to move further towards stricter arrangement of its currency, or even a joint dollar regime with Hong Kong and Macau.

The data sampled for each variable are constrained by data availability over economies. See Appendix A for data definitions and sources.

\subsection{Trade openness}

The OCA theory suggests that countries which trade a great deal with each other are good candidates for monetary integration as the benefits in terms of transaction cost savings and exchange rate certainty would be greatly enhanced (McKinnon, 1963). Accordingly, Bayoumi and Eichengreen (1997) have detected that European Member States which achieved the greatest levels of bilateral trade also experienced the greatest increase in their readiness for monetary unification.

A bilateral trade intensity measure, as used by Artis and Zhang $(2001,2002)$ and Boreiko (2003) is adopted here to measure a country's trade openness with the reference country. For each country denoted by $i$, trade openness with the US is measured by bilateral trade intensity, $\left(x_{i, r}+m_{i, r}\right) /\left(x_{i}+m_{i}\right)$ where $x_{i}$ and $m_{i}$ are the exports and imports of goods of the country and subscript $r$ indicates destination to or source from the US.

Figure 1

Trade Openness with US (\%), 1980-2009

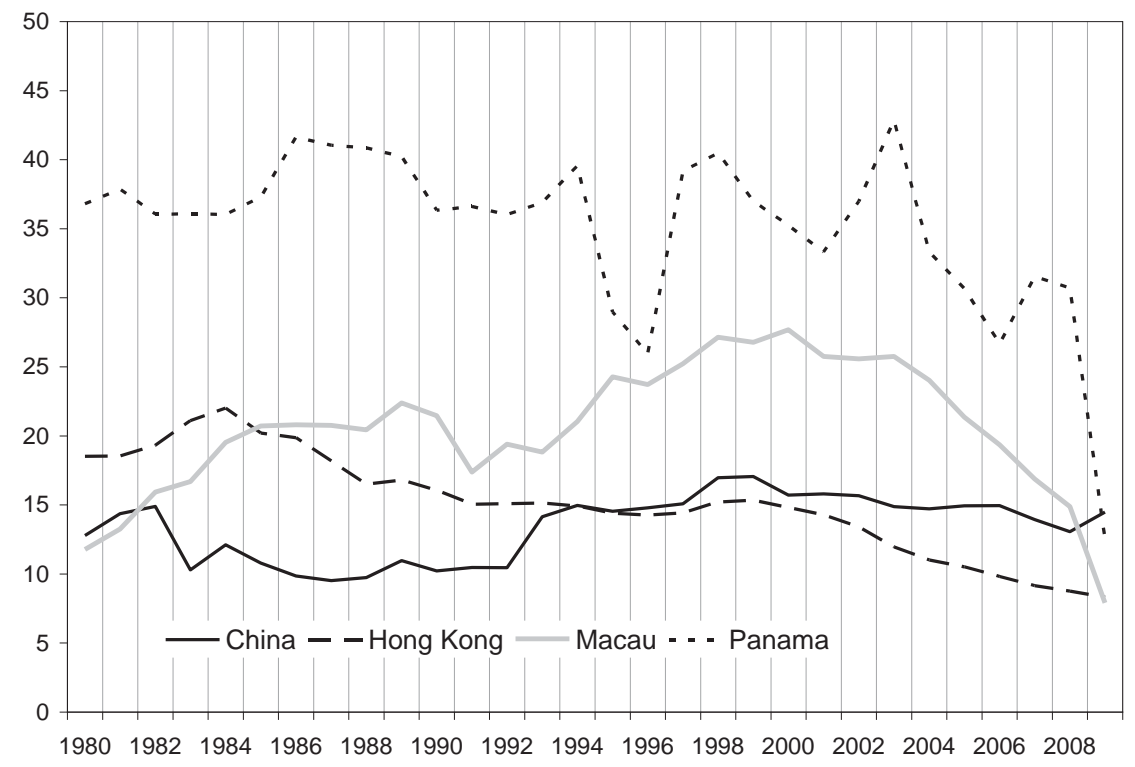

Source: See Appendix A. 
Figure 1 shows a chart depicting trade openness with the US for China, Hong Kong, Macau, and Panama in 1980-2009. It is apparent that Panama, a close neighbour to US boasts the greatest trade linkage with US showing only two sharp falls in 1995-96 and recently in 2009. The former drop was most probably due to economic stagnation in Panama during that period whilst the latter due to the recent economic crisis.

For China, its trade intensity with the US has reached a significantly higher level since 1993, reflecting the remarkable economic growth of about 8-9\% in the 1990s as a result of liberalization and privatization reforms besides China's accession into the Asia-Pacific Economic Cooperation (APEC) in 1991 which helped to promote trade and FDI, cooperation, and transfers of technology with other members particularly the US. Moreover, 1994 was China's banner year for financial reforms both in domestic taxation and in the organization of foreign trade (McKinnon and Schnabl, 2009).

For Hong Kong, its trade dependence on the US has been steadily declining since 1984, the year the dollar-based currency board was restored. Similarly, Macau's trade linkage with the US has been decreasing quite significantly since the early 2000s. For both of them, the lesser dependence on US could have been a result of diversification in trading partners. ${ }^{4}$

The chart also shows that the Chinese trade relation with US has been quite robust despite the recent crisis and could even be potentially larger than that of Hong Kong, Macau, or Panama in the future. ${ }^{5}$

\subsection{Business cycle synchronization}

When business cycles are substantially synchronized between two countries, the argument for flexible exchange rates to serve as a shock absorber to resolve asymmetric recessionary or inflationary pressures becomes largely irrelevant. In light of this, the higher the business cycle synchronization with the US, the stronger the argument for adopting the US monetary policy.

In terms of measurement, it has become popular to implement this OCA criterion according to the synchronicity of business cycles by evaluating the cyclical component of output at business cycle frequencies. In this paper, the method of Gerlach (1988) and Baxter and Stockman (1989) is adopted where cyclical components of annual real GDP series are detrended using Hodrick-Prescott (H-P) filter. Since the real GDP index series from the IMF are used in the analysis, the filtered series are directly comparable without any further transformations.

4 One possible facilitator to diversification in trading partners is their stable exchange rate to the international invoice currency of the US dollar. Moreover, given China's liberalizations and their geographical proximity to the mainland, Hong Kong and Macau have traded more intensively with China, hence reducing their relative reliance on US.

5 According to McKinnon (1963), a relatively open economy will tend to experience more fluctuations in the general price index which reduces the liquidity functions of money. Also, nominal exchange rate changes in that economy were not likely to be accompanied by significant effects on competitiveness because such changes would lead to rapid and large offsetting changes in domestic wages and prices. In this connection, given the increasingly open and export-led economy of China, pegging the yuan rate to the international dollar appears to be consistent with this argument. 

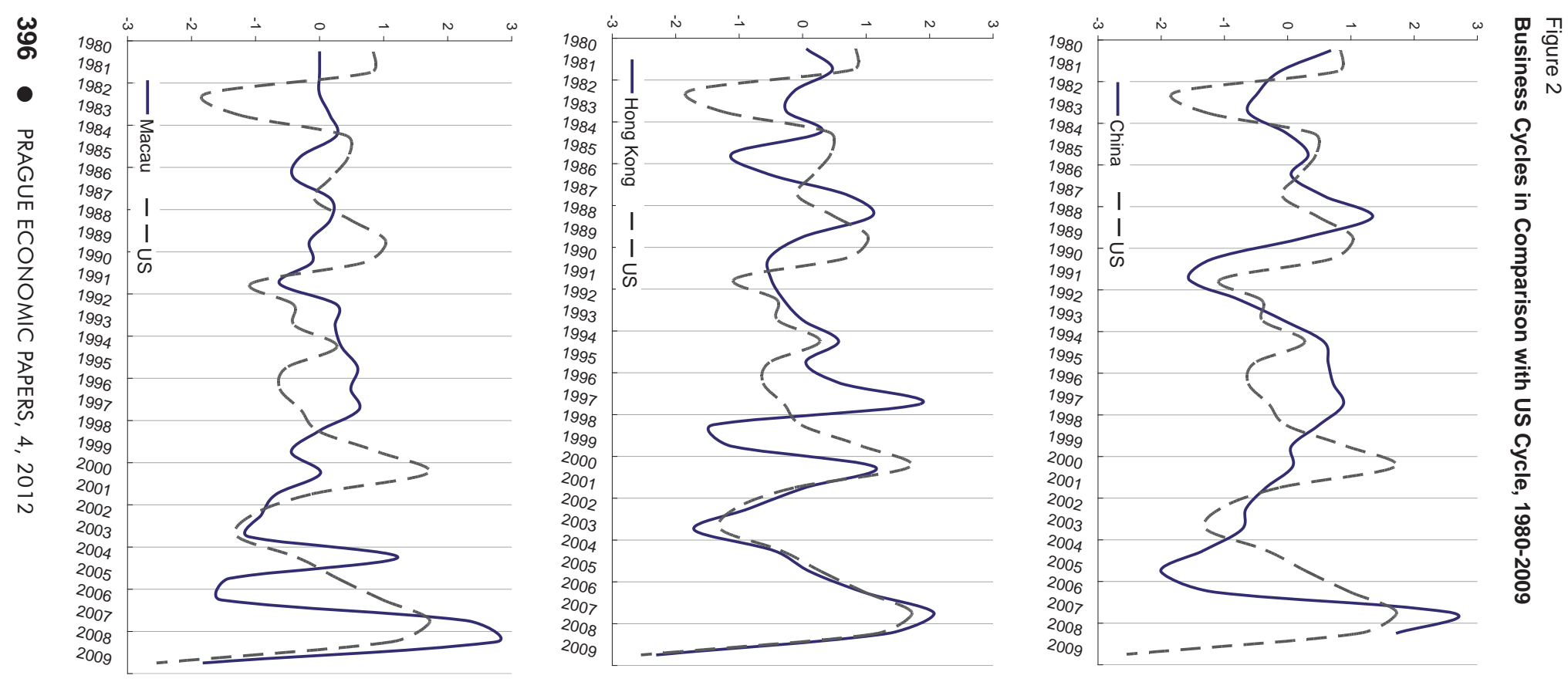


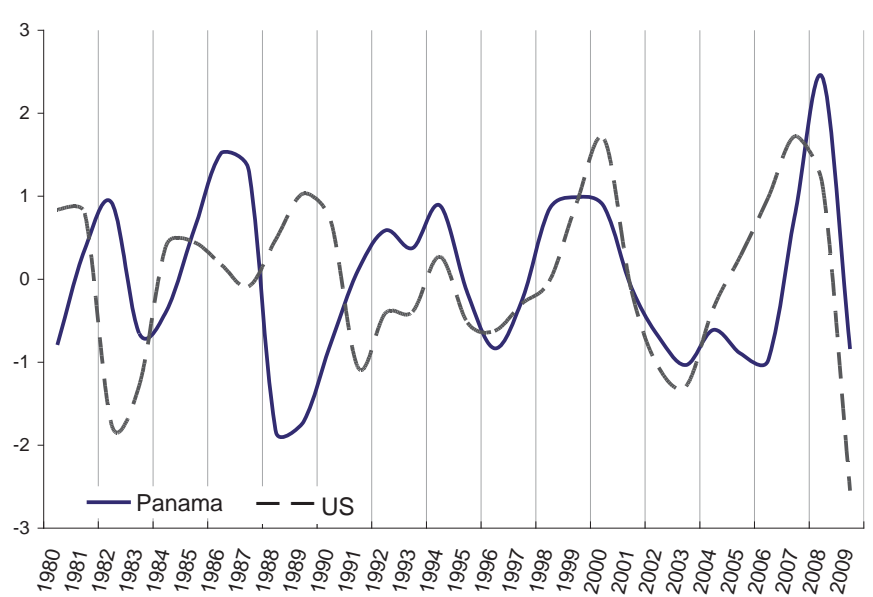

Source: See Appendix A.

Figure 2 compares the business cycle of each of the economies with the US cycle for 1980-2009. Firstly, since Hong Kong's return to the dollar peg in 1983 its business cycle has been considerably similar to the US cycle with significant divergences only in the early years of the rigid peg (due to undervaluation of the HK dollar at the onset) and following the 1997-98 Asian crisis. Since 2000 the HK cycle has virtually converged with the US cycle. Meantime, the Panamanian cycle has become noticeably more synchronous with the US cycle since the early 1990s whereas the Macanese cycle the least or not synchronous with the US one for the period sampled.

For China, its real growth movement is remarkably synchronous with the US's in the mid-1980s to early-1990s and also somewhat so in 2007-08 but is notably unrelated with the US cycle in 1995-2005, the period of fixed yuan-dollar rate. ${ }^{6}$ In another respect, the general rise-and-fall pattern across the countries in recent years can be ascribed to the US subprime crisis.

In light of the above, the Chinese cycle does not appear to be as synchronous with the US cycle as Hong Kong's or Panama's. Even when the change in real growth rate was used (see Appendix B), China's growth pattern is still not significantly associated with that of US.

\subsection{Real exchange rate volatility}

Real exchange rate variability is one indicator of synchronicity of economic forces between countries. The level of a country's need for real exchange rate changes is

6 The relatively stable growth pattern in China in 1995-2005 was likely the result of the exchange rate fixation which was intended to anchor domestic price level and to stabilize the rate of growth. 
an important determining factor for joining a monetary union because real exchange rate changes are clearly measurable and automatically give the appropriate weights to the economic forces of which they are the result (Vaubel, 1978). These economic forces pertain to inflation rates, openness, economy size, prices, wage flexibility, factor mobility, commodity diversification, goods market integration, and fiscal integration (Tavlas, 1993). Artis and Zhang (1997) suggested that low real exchange rate volatility might indicate absence of asymmetric shocks and presence of business cycle conformity that may strengthen the case for a currency area.

Figure 3 displays the real exchange rate movements against the US dollar in 1987-2009. Change in real exchange rate is represented by log-difference of monthly real bilateral exchange rates against the US dollar $\left(\mathrm{x} 10^{2}\right)$ using relative consumer prices. It is apparent that variations in the real dollar rate of the Chinese yuan have reduced significantly since the 1995-2005 yuan-dollar peg. Though the degree of stability of the yuan-dollar rates has not reached the level of Panama or Macau, it has nevertheless been moving toward that of Hong Kong.

Figure 3

Log-Difference of Monthly Real Bilateral Exchange Rates against US (x10²), 1987:1-2009:12

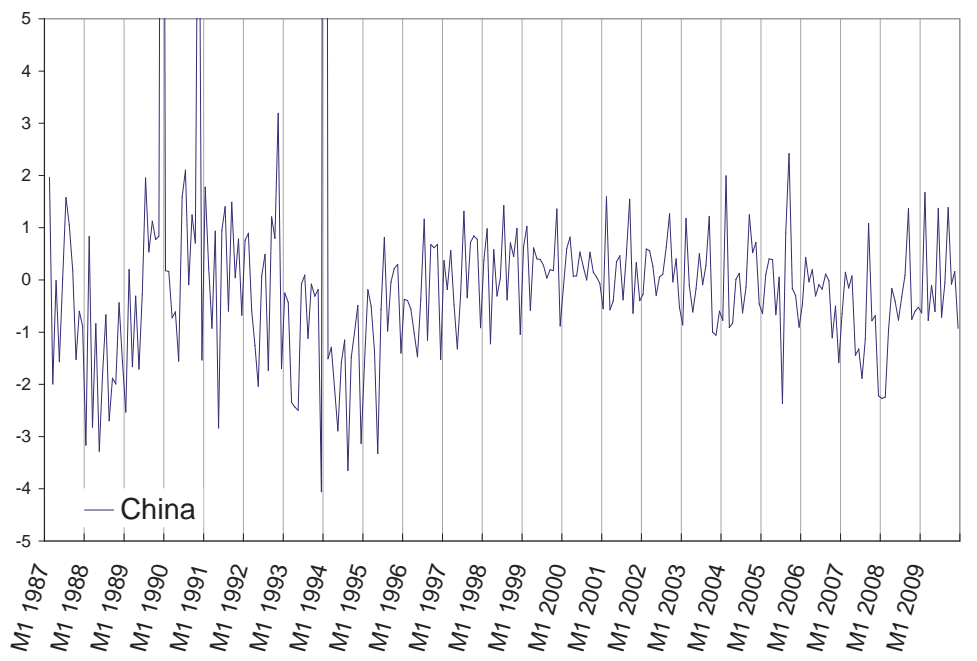



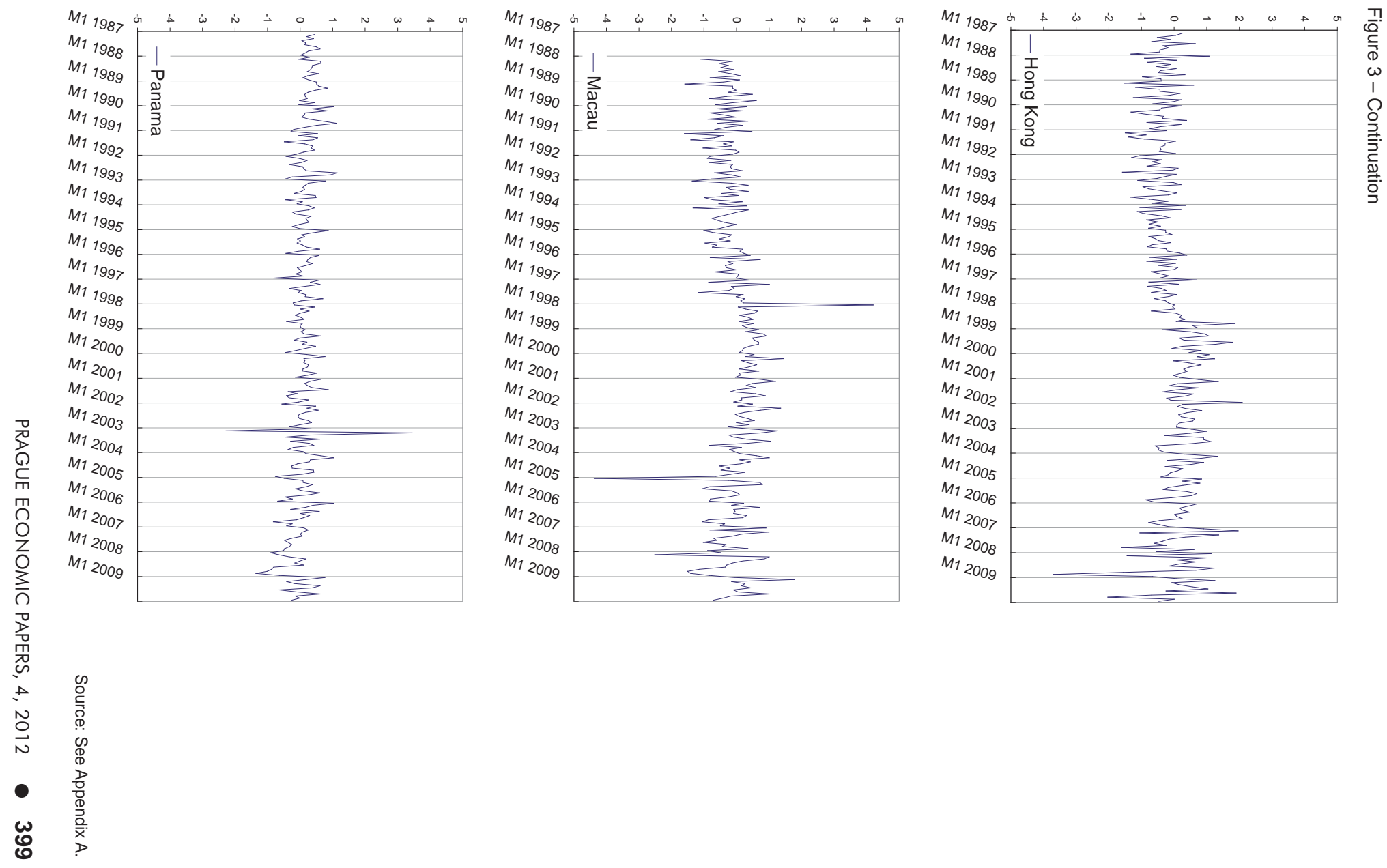


\subsection{Inflation convergence}

The traditional OCA literature originated during the era of 'fix-price' economics, so introducing inflation convergence as a criterion could be regarded simply as an appropriate normalization (Artis and Zhang, 2001). Since similar inflation rates result from similarities in monetary and fiscal policy stances and economic structure, the cost of joining a currency area is presumably low when inflation rates are similar across members (Nguyen, 2007). Convergence in inflation also reflects similarity in the degree of trade union aggressiveness and in labour costs between countries, implying lesser need for flexibility in nominal exchange rates to adjust current account imbalances (Fleming, 1971). Convergence in inflation is of course the central theme of the Maastricht Treaty. This criterion is measured by the absolute inflation differential, where and is the rate of inflation in country and the US respectively. The absolute value is used since the magnitude is of concern here.

Figure 4

Inflation Differentials with US (\%), 1987:1-2009:12

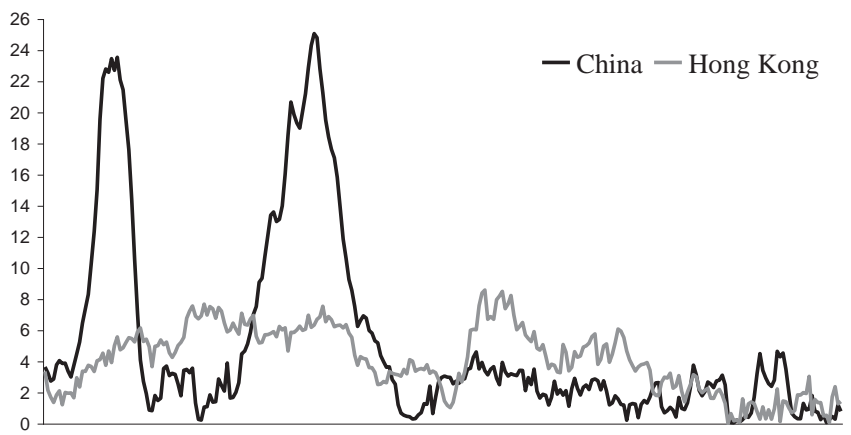

की

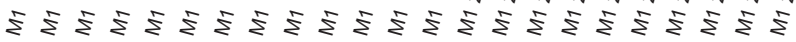

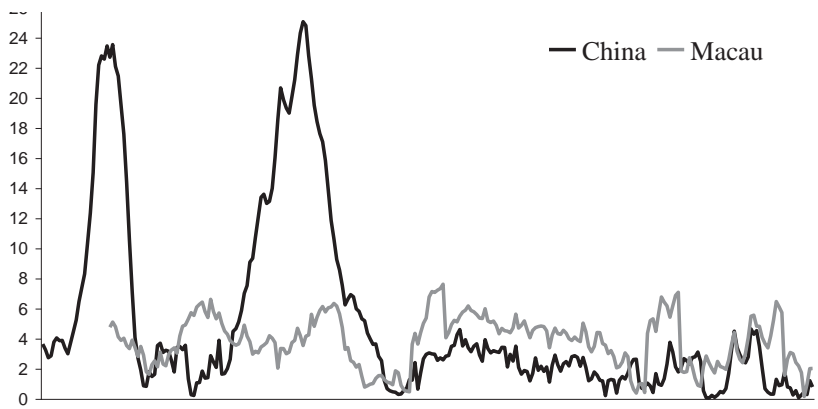

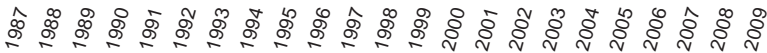

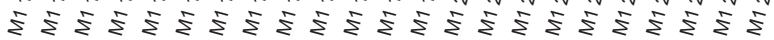


Figure 4 - Continuation

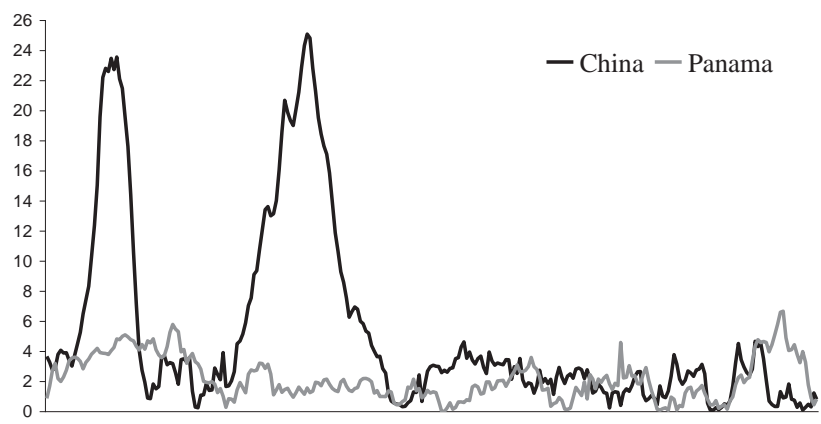

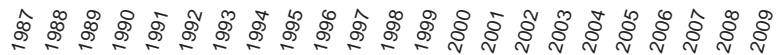

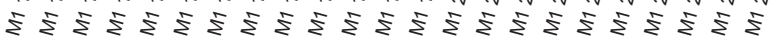

Source: See Appendix A.

Note: Each line in the charts represents inflation differential with US, hence the charts are comparing differentials with US between the economies.

Figure 4 puts together the 1987-2009 inflation differentials of the countries with the US. The largest divergence from the US inflation was reported by China in 1993-95 because of extremely high inflation in China, most likely due to the over-borrowing and -investment by the Chinese local governments in the early 1990s. ${ }^{7}$ Clearly, the inflation differential of China began to fall in $1995^{8}$, following the onset of the 1995-2005 dollar peg to extremely low levels until the Asian crisis and has somewhat levelled off at 2-4\% during the 2000s. Indeed, the Chinese inflation rate after the Asian crisis is at least as convergent with the US level as those of Hong Kong, Macau, and Panama. This could be primarily attributed to the sterilization of money inflows implemented by the Chinese monetary authorities in their attempt to control the domestic monetary base and hence the inflation rate.

\subsection{Real interest rate synchronization}

Though not listed as one of the criteria based on the traditional OCA theory (Tavlas, 1993), this factor is indicated by a 'revealed preference' argument (Artis and Zhang, 2001). If the monetary policy of a candidate country historically has differed little from that of the reference country, the cost of relinquishing monetary independence should be accordingly low, so that synchronization in real interest rates may be interpreted as an indicator of coordination in monetary policy.

7 See Fan Gang's commentary at http://www.project-syndicate.org/commentary/fan16/English (Accessed June 28, 2010) for a discussion on China's pro-active economic policies.

8 In 1994 the consolidated official exchange rate was set at RMB8.7/USD. Though this represented a substantial devaluation of the official rate from RMB5.8/USD, the nominal depreciation of the official rate was about the same order of magnitude of the excess of China's inflation over that prevailing in the US (McKinnon and Schnabl, 2009). Hence, real depreciation if any was minimal and as a result trade relations with US were not adversely impacted as can be seen in the rising Sino-US trade intensity discussed earlier. 
The more synchronous the real interest rate cycle to that of the US, the more coordinated the monetary policy. For comparability over countries, lending rate and CPI inflation rate are used and detrended series are normalized. Following Artis and Zhang (2001, 2002), detrending is accomplished by applying the H-P filter as in the synchronization in the business cycle criterion. Figure 5 compares each of the countries' real interest rate cycles with the US cycle in 1987-2009. For most of the period, the movement of the Chinese rate has been fairly different from the US one in direction or magnitude or both. Whilst in recent years the direction of the rate movement in China had been comparatively parallel with the American, its magnitude was somehow smaller. For the other economies, quite the opposite, as their cycles seem to have noticeably synchronized with the US cycle in both direction and magnitude in the same period. This is not unexpected since the Chinese monetary authorities have been sterilizing inflows of dollars to pursue monetary policy goals which cater to its national needs in the past two decades. ${ }^{9}$

Figure 5

Standardized Real Interest Rate Cycles in Comparison with US Cycle, 1987:1-2009:12

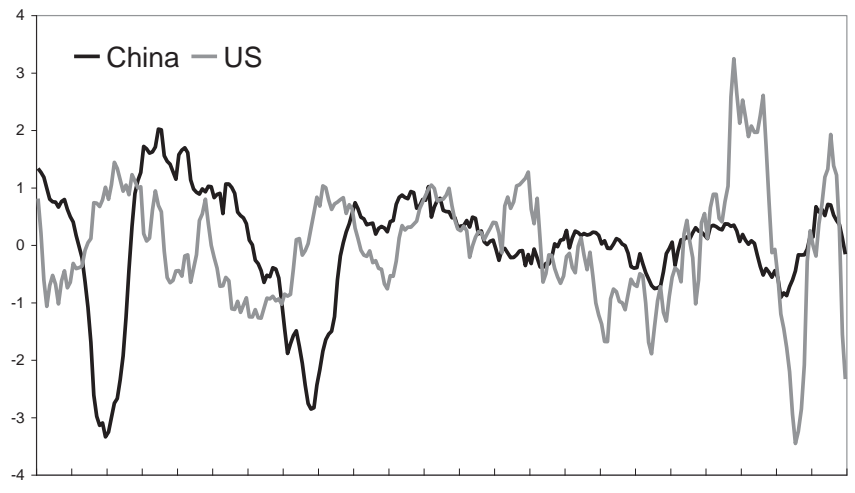

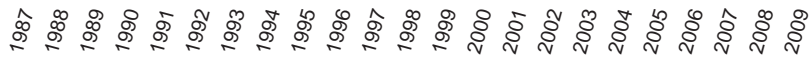

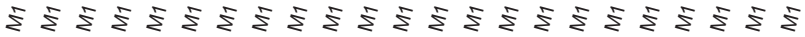

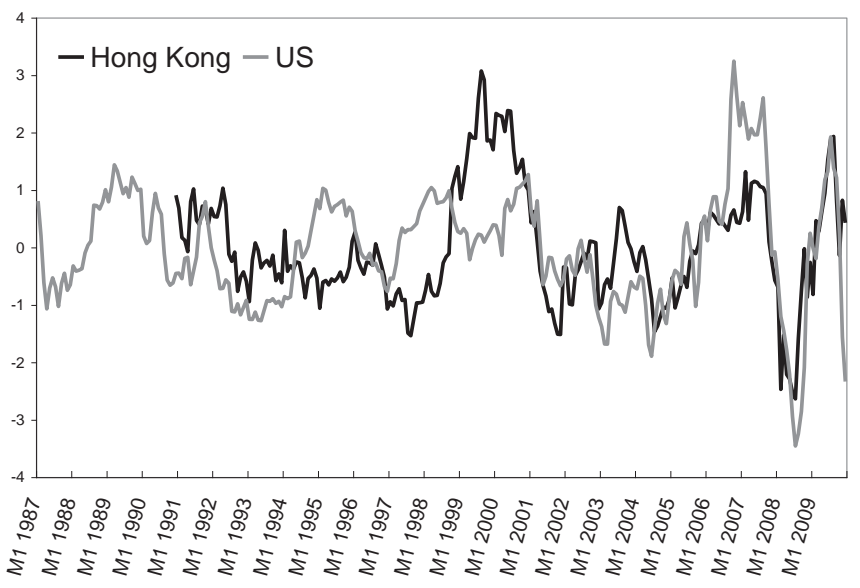

9 Once again, see Fan Gang's commentary as cited above. 
Figure 5 - Continuation

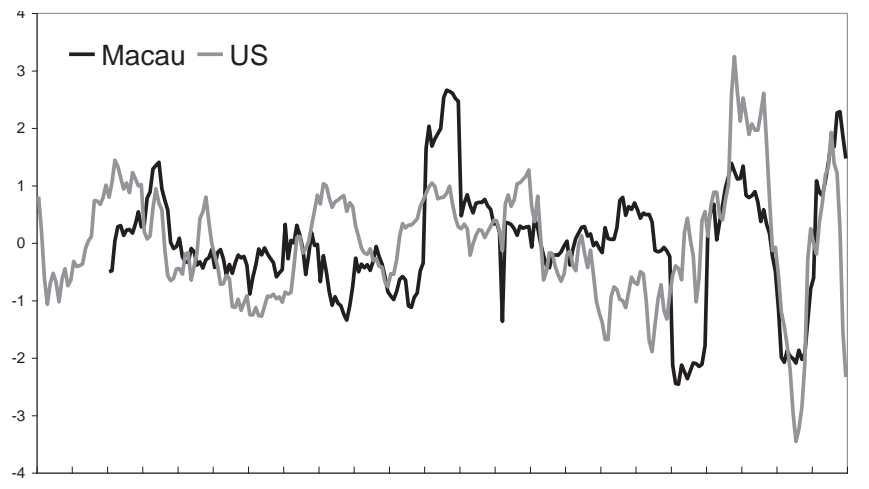

क ळ ळ

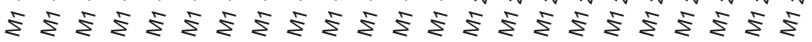

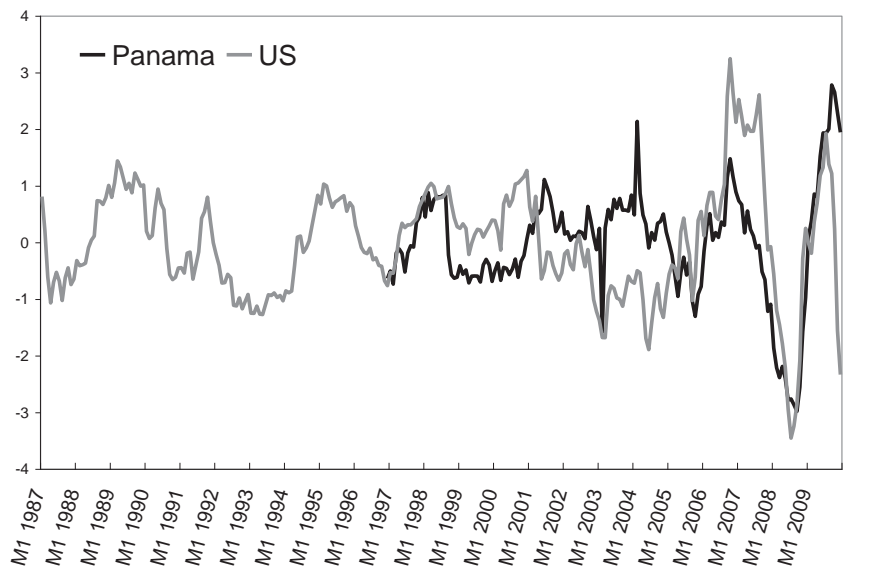

Source: See Appendix A.

In another respect, as shown by the charts, there seems to be a common movement of real lending rates in recent years across all economies. One possible explanation is the transmission of nominal interest rate changes through the US capital markets and the Fed's policy responses after the housing market bust whilst at the same time inflation rates in these economies have fallen or not changed much amidst the global downturn in growth.

\subsection{Export diversification}

For a diversified economy, even if its export sector is subject to shocks, if the shocks are independent and the country produces a sufficiently large variety of different goods, the law of large numbers will come into play and total production will not suffer much (Kenen, 1969). Accordingly, Dreyer (1978) evidenced that high export diversification is associated with policies to limit exchange rate flexibility whilst Honkapohja and Pikkarainen (1992) found that countries with well diversified exports have adopted more rigid exchange rate arrangements. 
In this paper, as in Nguyen (2007) the degree of export diversification is measured by the inverse of the period average of the annual Herfindahl index, a popular indicator of the degree of specialization. The Herfindahl index is computed as where is share of the export of product $i$, and is the number of products exported. Since data of individual export products are unavailable, annual export data according to the firstdigit sub-industries of the United Nation's Standard International Trade Classification (SITC) Revision 2 are used, as shown in Table 1.

Table 1

\section{United Nation's Standard International Trade Classification (SITC) Revision 2}

\begin{tabular}{|l|l|}
\hline Code & Product type \\
\hline $\mathbf{0}$ & Food and live animals \\
\hline $\mathbf{1}$ & Beverages and tobacco \\
\hline $\mathbf{2}$ & Crude minerals, inedible, except fuels \\
\hline $\mathbf{3}$ & Mineral fuels, lubricants, and related materials \\
\hline $\mathbf{4}$ & Animal and vegetable oils, fats and waxes \\
\hline $\mathbf{5}$ & Chemicals and related products \\
\hline $\mathbf{6}$ & Manufactured goods classified chiefly by material \\
\hline $\mathbf{7}$ & Machinery and transport equipment \\
\hline $\mathbf{8}$ & Miscellaneous manufactured articles \\
\hline $\mathbf{9}$ & Commodities and transactions not classified elsewhere \\
\hline
\end{tabular}

Source: Nguyen (2007).

Figure 6

\section{Export Diversification Indexes, 1981-2009}

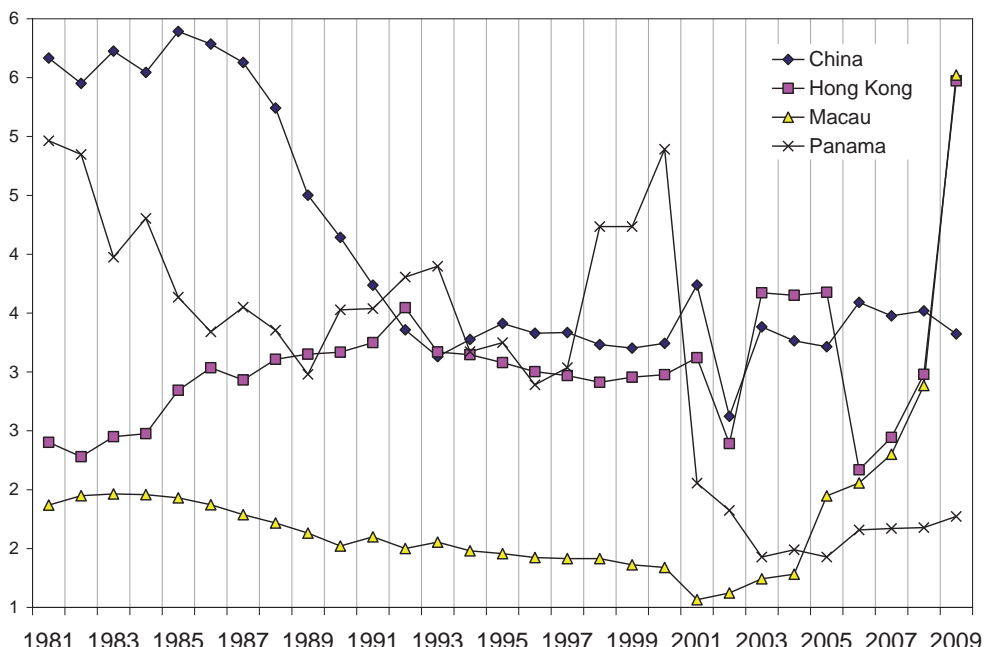

Source: See Appendix A. 
The 1981-2009 diversification indexes are presented in Figure 6. One can see that since mid-1980s, the Chinese exports have been less diversified or more specialized, reflecting the focus towards exports of manufactured goods and the benefits from economies of scale as openness to trade rises. The chart also shows that for 1991-1997 the Chinese index converges towards the levels of Hong Kong and Panama before staying quite in parallel with the HK level until 2005. In 2006-08, the Chinese diversification levels were once again greater than the others before being overtaken by Hong Kong and Macau in 2009. The recent rise in diversification in Hong Kong and Macau could have been a reaction to falling income from certain specific export sectors.

To summarize, by and large, in relative terms the Chinese exports can be regarded to be at least as diversified as those of Hong Kong, Macau, and Panama.

\subsection{Labour market flexibility}

Ingram (1962) and Kenen (1969) suggested that domestic labour market flexibility is equally important to transnational labour mobility (propounded by Mundell, 1961) to maintain employment in the face of shocks. Thus, for any economy the higher the flexibility of the labour market, the greater the ability to recover from any asymmetric shocks which lead to unemployment, and thus the greater the feasibility of entering a monetary union. One measure of the rigidity of labour markets that has been used in the literature (Artis and Zhang, 2001, 2002) is a ranking measure of the severity of employment protection legislation (EPL). In the same vein, an equivalent measure, the average of the indexes indicating rigidity by Doing Business Project (Table 2) by the World Bank, is used to measure labour market flexibility. The lower the index, the greater the degree of flexibility (see Botero et al., 2003). ${ }^{10}$

Table 2

Indexes Indicating Labour Market Rigidity

\begin{tabular}{|l|l|l|}
\hline & Index & Definition \\
\hline $\mathbf{1}$ & Difficulty of hiring & Difficulty of hiring a new worker \\
\hline $\mathbf{2}$ & Rigidity of hours & $\begin{array}{l}\text { Restrictions on expanding or contracting the number of working } \\
\text { hours }\end{array}$ \\
\hline $\mathbf{3}$ & Difficulty of firing & Difficulty and expense of dismissing a redundant worker \\
\hline $\mathbf{4}$ & Nonwage labour cost & Nonwage worker remuneration in percent of salary \\
\hline $\mathbf{5}$ & Firing cost & Cost of a redundant worker, expressed in weeks of wages \\
\hline
\end{tabular}

Source: Botero, Djankov, La Porta, Lopez-de-Silanes, and Schleifer (2003).

Macau data are not available. 
Figure 7

Labour Market Rigidity Indexes, 2004-2010

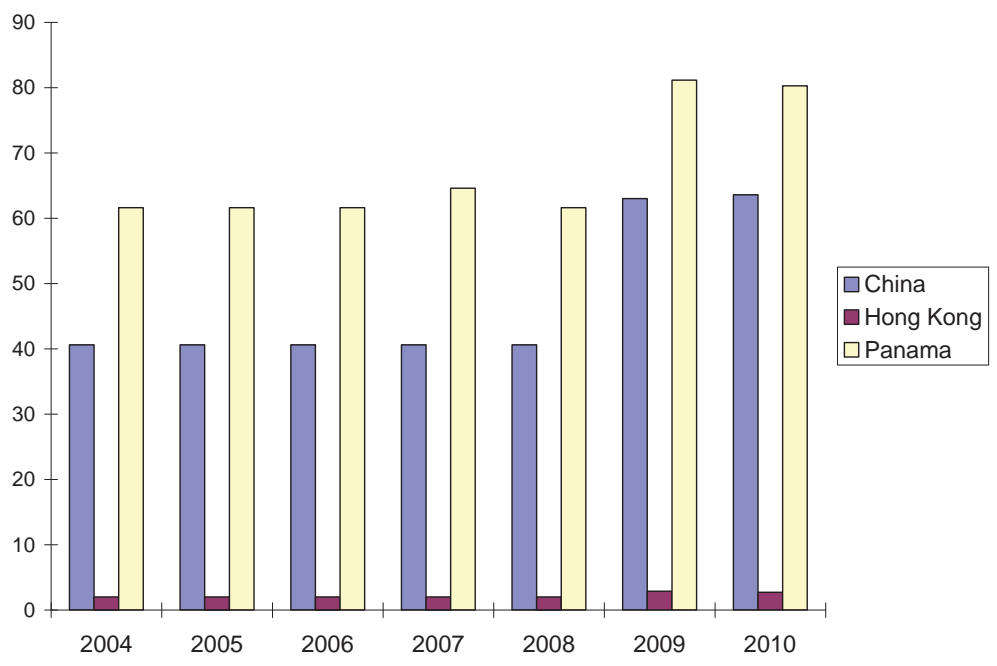

Source: See Appendix A.

Figure 8

Unemployment Rates, 1985-2009

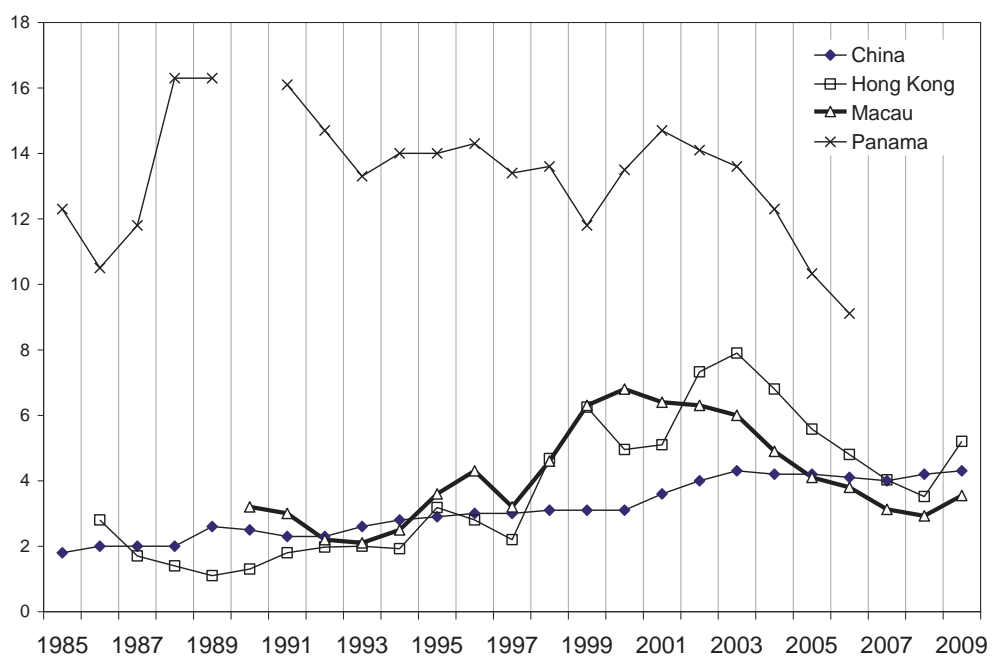

Source: See Appendix A.

Besides this measure, akin to Ngiam and Yuen (2001), unemployment rate can also be used as an indicator to reflect flexibility in the domestic labour market where lower rates might indicate greater flexibility. Figure 7 presents the labour market rigidity indexes. Immediately one can see that Hong Kong exhibits the lowest values, indicating the 
largest degree of labour flexibility, followed by China and Panama. Figure 8 plots the unemployment rates for 1985-2009, where available. Despite exhibiting a steady rise over the years, for most of the time unemployment rate (data are for urban areas) in China has been lower than the rest.

To our economic knowledge, labour market in China would be expected to deliver greater labour market rigidity and unemployment than elsewhere given the remnants of a centrally planned economy in much of the country, so the lower unemployment rates in China are likely due to the exceptional growth achieved in urban areas over this period. Nonetheless, it is quite clear that labour market in China is more flexible than Panama's. ${ }^{11}$

\section{Discussion and Conclusion}

The preceding discussion attempted to evaluate the appropriateness of China for a dollar peg in terms of the OCA-related criteria using Hong Kong, Macau, and Panama as potential benchmarks. Direct comparisons with Hong Kong, Macau, and Panama, economies with effective fixed dollar rates, to some extent might mitigate the endogeneity problem of the OCA approach. At the same time this approach might also signify the prospects for a joint dollar regime among the Chinese economies. Based on the measures, the following findings can be drawn.

With respect to trade openness, China has traded more intensely with US than Hong Kong has, and there is potential for the Sino-US trade relation to be greater than that of Macau or Panama. In terms of business cycle symmetry, the Chinese cycle does not appear to be as synchronous with the US cycle as that of Hong Kong or Panama. Regarding real exchange rate stability, the stability level of the Chinese yuan resembles that of Hong Kong. In connection to inflation convergence with US, after the Asian crisis the inflation in China has been at least as convergent as those in Hong Kong, Macau, and Panama. Concerning real interest rate cycle synchronicity which approximates monetary policy symmetry, China has not shown relatively substantial level of symmetry with US. With regard to the variety of goods exported, the diversification levels of Chinese exports are at least as high as those of Hong Kong, Macau, and Panama. With respect to labour market flexibility, the labour market in China is probably more flexible than that of Panama.

Of all the "indicators" explored, except for business cycle symmetry and interest rate cycle symmetry, the rest of China's features appear to be fairly consistent with a fixed dollar peg, or at least not contrarian to a dollar regime when compared to our chosen benchmarks. Recall that the benchmarks with "hard" pegs too are not consistently in high degree of conformity with the criteria, what's more with China whose policies employ only a "soft" dollar peg. In addition, despite the divergences in economic objectives and level of economic development between China and US, there appears to be substantial conformity in terms of the dimensions explored on the Chinese side.

11 Both rigidity and unemployment measures suggest that labour market in Panama is more rigid than that in China. 
In conclusion, the findings appear to broadly support the prevailing dollar peg in China and it might be appropriate for China to at least maintain its present arrangement if not graduating towards a stricter dollar standard such as that established in Hong Kong, Macau, or Panama. This finding corroborates McKinnon and Schnabl (2009) who favour a stable yuan-dollar rate for the sake of regional stability and global economic growth. In addition to that, since no severe divergences are found between China, Hong Kong, and Macau, given strong political impetus which is highly possible amongst these Chinese states, a joint dollar-based bloc among them seems viable. This is in line with Zhang and Sato (2008) who detected a rising structural symmetry between the Greater China economies.

Nevertheless, the inferences found here are limited in the sense that economically Hong Kong, Macau, and Panama are much smaller and structurally different from China and hence the usefulness of the criteria might differ between them. But then again, the fact that Hong Kong and Macau are peripheral territories of China and do share many similarities with the mainland in social, political, and economic terms might make Hong Kong and Macau a plausible point of reference for China. This paper is also limited in the sense that it focuses only on economic dimensions but not political aspects, such as "loss of sovereignty" if China were to progress into a rigid regime which entails "kowtowing" to American monetary policies.

\section{APPENDIX A}

Table A.1

\section{Data Definitions and Sources ${ }^{1}$}

\begin{tabular}{|l|c|c|c|c|c|c|}
\hline Country & Trade $^{2}$ & $\begin{array}{c}\text { Real GDP index } \\
\text { (GDP Volume, } \\
\text { 2005=100) }\end{array}$ & $\begin{array}{c}\text { Exchange rate } \\
\text { Lending rate, } \\
\text { CPI }\end{array}$ & $\begin{array}{c}\text { Export }_{\text {structure }}{ }^{4} \\
\text { China }\end{array}$ & $\begin{array}{c}\text { Employing } \\
\text { workers } \\
\text { index }\end{array}$ & $\begin{array}{c}\text { Unemployment } \\
\text { rate }\end{array}$ \\
\hline Hong Kong & $80-09$ & $80-08$ & $87: 1-09: 12$ & $81-09$ & $04-10$ & $85-09$ \\
\hline Macau & $80-09$ & $80-09$ & $87: 1-09: 12$ & $81-09$ & $04-10$ & $86-09$ \\
\hline Panama & $80-09$ & $80-09$ & $87: 1-09: 12$ & $81-09$ & - & $90-09$ \\
\hline US & - & $80-09$ & $87: 1-09: 12$ & $81-09$ & $04-10$ & $85-89,91-06$ \\
\hline
\end{tabular}

Notes:

1. Series are from IMF-IFS database except stated otherwise. Sampled periods are selected as such to ensure greatest degree of consistency over countries.

2. Trade series are from IMF-DOTS database.

3. Exchange rate series are rates against the US dollar. CPI is used to compute real exchange rate.

4. Export structure data for 1981-2000 are extracted from NBER World Trade Flows database, whereas data for 2001-2009 are taken from International Trade Statistics, International Trade Center UNCTAD/WTO website, retrieved July 08, 2010, from http://www.intracen.org/tradstat/sitc3-3d/indexre.htm

5. Data are from the World Bank Group: Doing Business website. Retrieved June 08, 2010, from http://message. worldbank.org/external/external_error.htm 


\section{APPENDIX B}

To assess the relationship between US growth and those in Asia, Kwan (2001) and McKinnon and Schnabl (2003) regressed the real growth rates of Asian countries on that of the US. To overcome the problems caused by non-stationarity, we regress the yearly change in the real growth rates of China, Hong Kong, Macau, and Panama, respectively $\left(y_{j}\right)$ on that of the US $\left(y_{U S}\right) .{ }^{12}$ Similar to those of the previous authors, lagged regressors are not used since they did not yield significant results. The model is described by equation (1).

$$
y_{j_{t}}=\beta_{0}+\beta_{1} y_{U S_{t}}+u_{t}
$$

Table B.1 reports the estimated coefficients and some associated statistics. The table shows strong positive association between change in US real growth and each of those of Hong Kong and Macau. Based on the coefficients for every percent increase in the real growth rate in US, real growth rate in Hong Kong rises by about 1.03 percent while Macau's rises by about 1.95 percent. For China and Panama, the estimations are not significant. In summary, China, as well as Panama has not exhibited significant real output synchronicity with the US as compared with those demonstrated by Hong Kong or Macau.

Table B.3

Estimation Results for Change in Real Growth Rate (\%), 1982-2009

\begin{tabular}{|l|c|c|c|c|c|}
\hline \multicolumn{1}{|c|}{$\boldsymbol{J}$} & $\hat{\beta}_{1}$ & $\mathbf{R}^{2}$ & F-statistic & Durbin-Watson & Jarque-Bera \\
\hline China & $\begin{array}{c}0.30 \\
(1.26)\end{array}$ & 0.05 & 1.38 & 1.62 & 0.60 \\
\hline Hong Kong & $\begin{array}{c}1.03^{* * *} \\
(3.90)\end{array}$ & 0.19 & $6.29^{* *}$ & 2.39 & 0.58 \\
\hline Macau & $\begin{array}{c}1.95^{* * *} \\
(2.80)\end{array}$ & 0.15 & $4.38^{* *}$ & 2.31 & 1.00 \\
\hline Panama & $\begin{array}{c}-0.13 \\
(-0.31)\end{array}$ & 0.00 & 0.08 & 1.91 & 1.78 \\
\hline
\end{tabular}

Notes

1. Figures in parentheses denote $t$-values. *Significant at 10 percent level. **Significant at 5 percent level. *Significant at 1 percent level. $t$-values are based on Newey-West heteroskedasticity and autocorrelation consistent standard errors.

2. All Jarque-Bera statistics are not significant, hence assumption of normality of residuals is not violated.

3. Breusch-Godfrey Serial Correlation LM Test indicates no correlation between residual and regressor for all models.

12 As done by previous authors, we used yearly data because quarterly data on real GDP are not available for most cases for the whole observation period. Data series were checked to ensure stationarity. Based on Ljung-Box Q-statistic of up to 12 lags and Augmented Dickey-Fuller test (selection of number of lags based on Schwartz Information Criterion with maximum lags of 6), the change in real growth rates is stationary and hence used for all economies. 


\section{REFERENCES}

Artis, M., Zhang, W. (1997), "International Business Cycles and the ERM: Is there a European Business Cycle?" International Journal of Finance and Economics, 2, pp. 1-16.

Artis, M., Zhang, W. (2001), "Core and Periphery in EMU: A Cluster Analysis." Economic Issues, 6, pp. 39-60.

Artis, M., Zhang, W. (2002), "Membership of EMU: A Fuzzy Clustering Analysis of Alternative Criteria." Journal of Economic Integration, 17, pp. 54-79.

Baxter, M., Stockman, A. C. (1989), "Business Cycles and the Exchange-rate Regime." Journal of Monetary Economics, 27, pp. 377-400.

Bayoumi, T., Eichengreen, B. (1997), "Ever Closer to Heaven? An Optimum-Currency-Area Index for European Countries." European Economic Review, 41, pp.761-770.

Bayoumi, T., Mauro, P. (2001), "The Suitability of ASEAN for a Regional Currency Arrangement." The World Economy, 24(7), pp. 933-954.

Boreiko, D. (2003), "EMU and Accession Countries: Fuzzy Cluster Analysis of Membership." International Journal of Finance and Economics, 8, pp. 309-325.

Botero, J., Djankov, S., La Porta, R., Lopez-de-Silanes, F., Schleifer, A. (2003), "The Regulation of Labor." Quarterly Journal of Economics, 119, pp. 1339-1382.

Calvo, G. A. (1998), "Varieties of Capital Market Crises," in Calvo, G., King, M. eds. The Debt Burden and its Consequences for Monetary Policy. Macmillan.

Dreyer, J. S. (1978), "Determinants of Exchange-Rate Regimes for Currencies of Developing Countries: Some Preliminary Results." World Development, Volume 6, No. 4, pp. 437-445.

Fleming, J. M. (1971), "On Exchange Rate Unification.” Economic Journal, 81, pp. 467-88.

Frankel, J., Rose, A. (1998), "The Endogeneity of the Optimum Currency Area Criteria." Economic Journal, 108, pp.1009-1025.

Gerlach, S. (1988), "World Business Cycles under Fixed and Flexible Exchange Rates", Journal of Money, Credit and Banking, 20, pp. 621-632.

Hale, D. D., Hale, L. H. (2008), "Reconsidering Revaluation: The Wrong Approach to the U.S.-Chinese Trade Imbalance." Foreign Affairs, Vol. 87, No. 1, Council on Foreign Relations.

Honkapohja, S., Pikkarainen, P. (1992), "Country Characteristics and the Choice of the Exchange Rate Regime: Are Mini-Skirts Followed by Maxis?" CEPR Discussion Papers 744, C.E.P.R. Discussion Papers.

Ingram, J. (1962), Regional Payments Mechanisms: The Case of Puerto Rico. Chapel Hill: University of North Carolina Press.

Kenen, P. (1969), "A Theory of Optimum Currency Areas: An Eclectic View“, in Mundell, R. A., Swoboda, A. K. eds. Monetary Problems of the International Economy. Chicago: University of Chicago Press.

Krugman, P. (2010), "The Renminbi Runaround." The New York Times, June 24, 2010. http://www. nytimes.com/2010/06/25/-opinion/25krugman.html?ref=paulkrugman (accessed June 28, 2010).

Kwan, C. H. (2001), Yen Bloc: Toward Economic Integration in Asia. Brookings Institution Press, Washington, D.C.

McKinnon, R. (1963), "Optimum Currency Areas." American Economic Review, 53, pp. 717-725.

McKinnon, R. I., Schnabl, G. (2003), "Synchronized Business Cycles in East Asia and Fluctuations in the yen-dollar Exchange Rate." The World Economy, 26, pp. 1067-1089.

McKinnon, R., Schnabl, G. (2009), "The Case for Stabilizing China's Exchange Rate: Setting the Stage for Fiscal Expansion." China \& World Economy, 17, pp. 1-32.

Mundell, R. (1961), "A Theory of Optimum Currency Areas." American Economic Review, 51, pp. 657-664. 
Ngiam, K. J., Yuen, H. (2001), "Monetary Cooperation in East Asia: A Way forward." The Singapore Economic Review, 46(2), pp. 211-246.

Nguyen, T. (2007), "East Asian Currency Area: A Fuzzy Clustering Analysis of Homogeneity." Development and Policies Research Center Working Paper No. 10, DPRC, Vietnam.

Park, Y. C. (2010), "RMB Internationalization and Its Implications for Financial and Monetary Cooperation in East Asia." China \& World Economy, 18: pp. 1-21.

Peng, T., Lee, M., Gan, C. (2008), "Has the Chinese Currency Been Undervalued?" Journal of Chinese Economic and Business Studies, 6(1), pp. 49-66.

Quah, C. H., Crowley, P. M. (2010), "Monetary Integration in East Asia: A Hierarchical Clustering Approach." International Finance 13(2), pp. 283-309.

Quah, C. H. (2012a), "Is East Asia as prepared as Eurozone for monetary union?" Journal of Business, Economics, and Management, 13(3), pp. 471-488.

Quah, C. H. (2012b), "Can Japan or China replace the US as the monetary anchor for Hong Kong and Macau?" Asia Pacific Business Review, 18(3), pp. 335-354.

Quah, C. H. (2012c), "The Case for Monetary Union in East Asia: From Theory to Empirics in Business Management", In Tech Open Access Publisher, Rijeka, Croatia.

Quah, C. H., Ismail, M. N. (2012), "Monetary Integration in East Asia: A Critical Review." Actual Problems of Economics, 4 (April).

Quah, C. H., Patrick M. Crowley (2012), "Which country should be the monetary anchor for East Asia: the US, Japan or China?" Journal of the Asia Pacific Economy, 17(1), pp. 94-112

Tavlas, G. (1993), "The 'New' Theory of Optimum Currency Areas." The World Economy, 16, pp. 663-685.

Vaubel, R. (1978), Strategies for Currency Unification. Tubingen: J. C. B. Mohr.

Wu, F., Pan, R., Wang, D. (2010), "Renminbi's Potential to Become a Global Currency." China \& World Economy, 18, pp. 63-81.

Zhang, J., Fung, H-G., Kummer, D. (2006), "Can Renminbi Appreciation Reduce the US Trade Deficit?" China and World Economy, 14 (1), pp. 44-56.

Zhang, Z., Sato, K. (2008), "Whither a Currency Union in Greater China?" Open Economies Review, 19(3), pp. 355-370. (Retrieved August 10, 2008, from SpringerLink database.) 